\title{
Determinants of Deescalation Failure in Critically Ill Patients with Sepsis: A Prospective Cohort Study
}

\author{
Nawal Salahuddin, ${ }^{1}$ Lama Amer, ${ }^{2}$ Mini Joseph, ${ }^{3}$ Alya El Hazmi, ${ }^{4}$ \\ Hassan Hawa, ${ }^{4}$ and Khalid Maghrabi ${ }^{1}$ \\ ${ }^{1}$ King Faisal Specialist Hospital \& Research Center, Riyadh 11211, Saudi Arabia \\ ${ }^{2}$ Department of Medicine, King Faisal Specialist Hospital \& Research Centre, Riyadh 11211, Saudi Arabia \\ ${ }^{3}$ Department of Nursing, King Faisal Specialist Hospital \& Research Centre, Riyadh 11211, Saudi Arabia \\ ${ }^{4}$ Adult Critical Care Medicine, King Faisal Specialist Hospital \& Research Center, Riyadh 11211, Saudi Arabia
}

Correspondence should be addressed to Nawal Salahuddin; salahuddin.nawal@gmail.com

Received 27 March 2016; Revised 11 June 2016; Accepted 15 June 2016

Academic Editor: Samuel A. Tisherman

Copyright (c) 2016 Nawal Salahuddin et al. This is an open access article distributed under the Creative Commons Attribution License, which permits unrestricted use, distribution, and reproduction in any medium, provided the original work is properly cited.

\begin{abstract}
Introduction. Deescalation refers to either discontinuation or a step-down of antimicrobials. Despite strong recommendations in the Surviving Sepsis Guidelines (2012) to deescalate, actual practices can vary. Our objective was to identify variables that are associated with deescalation failure. Methods. In this prospective study of patients with sepsis/septic shock, patients were categorized into 4 groups based on antibiotic administration: no change in antibiotics, deescalation, escalation (where antibiotics were changed to those with a broader spectrum of antimicrobial coverage), or mixed changes (where both escalation to a broader spectrum of coverage and discontinuation of antibiotics were carried out). Results. 395 patients were studied; mean APACHE II score was $24 \pm$ 7.8. Antimicrobial deescalation occurred in 189 (48\%) patients; no changes were made in 156 (39\%) patients. On multivariate regression analysis, failure to deescalate was significantly predicted by hematologic malignancy OR $3.3(95 \%$ CI $1.4-7.4) p<0.004$, fungal sepsis OR 2.7 (95\% CI 1.2-5.8) $p=0.011$, multidrug resistance OR 2.9 (95\% CI 1.4-6.0) $p=0.003$, baseline serum procalcitonin OR 1.01 (95\% CI 1.003-1.016) $p=0.002$, and SAPS II scores OR 1.01 (95\% CI 1.004-1.02) $p=0.006$. Conclusions. Current deescalation practices reflect physician reluctance when dealing with complicated, sicker patients or with drug-resistance or fungal sepsis. Integrating an antibiotic stewardship program may increase physician confidence and provide support towards increasing deescalation rates.
\end{abstract}

\section{Introduction}

Early administration of broad-spectrum, empiric antimicrobial therapy reduces mortality and improves outcomes in patients with severe sepsis and septic shock. However, broadspectrum therapy favors the emergence of drug-resistance and adds excessively to the costs of care. Deescalation refers to a strategy whereby clinicians either discontinue or change to a narrower spectrum antimicrobial drug and is usually carried out after culture results become available. The objective of this study was to identify variables associated with deescalation failure.

\section{Methods}

This study is reported following the STROBE statement checklist for observational studies [1].

2.1. Ethics, Consent, and Permissions. The institutional Office of Research Affairs (ORA) and ORA Research Ethics Committee approved the study methods (RAC number 2131108). The Research Ethics Committee waived patient consent based on the study design. The study was performed in accordance with the ethical standards laid down in the 1964 Declaration 
TABLE 1: Characteristics of patients.

\begin{tabular}{lc}
\hline Patient characteristics & $n=395$ \\
\hline APACHE II score & $24 \pm 7.8$ \\
\hline Serum procalcitonin & $3.9(\mathrm{IQR} 25 \% 1.1,75 \%$ \\
\hline Admission during working hours & $187(37 \%)$ \\
Admission after working hours & $248(63 \%)$ \\
\hline Vasopressors at 72 hours & $236(60 \%)$ \\
\hline Comorbid illnesses & \\
Malignancy & $86(22 \%)$ \\
$\quad$ Metastatic cancer & $26(7 \%)$ \\
$\quad$ Hematologic malignancy & $35(9 \%)$ \\
Acute respiratory failure & $67(17 \%)$ \\
Chronic renal failure & $64(16 \%)$ \\
Dialysis dependent & $42(11 \%)$ \\
Cirrhosis & $62(16 \%)$ \\
Chronic diseases ${ }^{*}$ & $235(59 \%)$ \\
\hline No microbial growth on admission cultures & $200(51 \%)$ \\
\hline Source of sepsis &
\end{tabular}

* refers to chronic medical illnesses, that is, type 2 diabetes mellitus, coronary artery disease, and hypertension.

of Helsinki and its later amendments. No individual patient data is presented.

2.2. Study Design and Setting. In this prospective, cohort study we reviewed consecutive adult ( $>14$ years) patients admitted to the intensive care unit (ICU) with a diagnosis of sepsis or septic shock. The period of study was from 1st January 2013 to 1st January 2014. Patients who were not for resuscitation (DNR) or were expected to die within 48 hours were excluded.

2.3. Operational Definitions. Antibiotic therapy was considered appropriate based on in vitro sensitivity on culture. On day 7 after ICU admission, we categorized patients into four groups based on antibiotic administration: no change in antibiotics, deescalation (defined as stopping or changing to a narrower spectrum antibiotic), escalation (where antibiotics were changed to those with a broader spectrum of antimicrobial coverage), or mixed changes (where both escalation
TABLE 2: Frequencies of all microbial isolates.

\begin{tabular}{lc}
\hline Organisms isolated & Number $^{\star}$ \\
\hline Enterobacteriaceae* $^{*}$ & $57(29.2 \%)$ \\
\hline Pseudomonas aeruginosa & $53(27.1 \%)$ \\
\hline GPC $^{\wedge}$ & $21(10.7 \%)$ \\
\hline Fungal & $25(12.8 \%)$ \\
Candida albicans & $11(5.6 \%)$ \\
Candida non-albicans & $13(6.6 \%)$ \\
Aspergillus & 1 \\
\hline Stenotrophomonas maltophilia & $8(4 \%)$ \\
\hline MRSA & $7(3.5 \%)$ \\
\hline Acinetobacter baumannii & $7(3.5 \%)$ \\
\hline VRE & $5(2.5 \%)$ \\
\hline Viruses $^{\#}$ & $3(1.5 \%)$ \\
\hline Miscellaneous & \\
\hline
\end{tabular}

${ }^{\star}$ Out of 195 positive cultures; * includes Escherichia coli, Klebsiella, Enterobacter, Citrobacter koseri, and Proteus mirabilis; $\wedge$ includes Streptococcus sp. and methicillin-sensitive Staphylococcus aureus; \# includes MERS-corona, parainfluenza, and influenza; $\wedge$ includes Alcaligenes xylosoxidans, Vibrio cholerae, Mycobacterium tuberculosis, and Nocardia.

to a broader spectrum of coverage and discontinuation of antibiotics were carried out).

2.4. Statistical Analysis. Continuous data was tested for normality; measures of central tendency were reported as means \pm standard deviations (SD) and compared using Student's $t$ test for normally distributed variables and reported as medians (interquartile range, IQR) and compared using the MannWhitney $U$ test for skewed data. Categorical variables were compared using the $\chi^{2}$ test or the Fisher Exact test for $n<$ 5. Logistic regression analysis was performed to determine the predictive ability of variables for antibiotic deescalation. Univariate and multivariate techniques were used, and, for multivariate regression, a backward mode with a threshold 0.10 was used for elimination. Multivariate associations were reported as odds ratios, $\operatorname{Exp}(B)$ with $95 \%$ confidence intervals. A two-sided $p$ value of $<0.05$ was considered as statistically significant. All analyses were carried out using IBM SPSS version 22.0.

\section{Results}

Three hundred and ninety-five patients were included in the study; 194 (49\%) were female, mean age of $52.4 \pm 12$ years; mean APACHE II and SAPS II scores were $24 \pm 7.8$ and $45 \pm$ 19.7. Three hundred and thirty-three $(84.3 \%)$ patients were admitted from within the hospital, 58 (14.7\%) were admitted from the emergency department, and 4 (1\%) came as interhospital transfers via MEDEVAC. Two hundred and fortyeight patients $(62.8 \%)$ were admitted after regular working hours (4:30 pm to 7:30 am); of these, 214 (86\%) came from in-hospital wards, 30 (12\%) from the emergency department, and $4(2 \%)$ as transfers. Only $195(49.3 \%)$ of the total 395 patients had positive cultures. Nosocomial acquisition of sepsis was confirmed in 105 [75\%] of 139 culture-positive patients 
TABLE 3: Differences in patient characteristics by final antibiotic grouping.

\begin{tabular}{|c|c|c|c|c|c|}
\hline & $\begin{array}{c}\text { Deescalation } \\
(n=189)\end{array}$ & $\begin{array}{l}\text { No change } \\
(n=156)\end{array}$ & $\begin{array}{c}\text { Escalation } \\
(n=42) \\
\end{array}$ & $\begin{array}{l}\text { Mixed changes } \\
\quad(n=8)\end{array}$ & $p$ value \\
\hline SAPS II & $48 \pm 19.5$ & $41 \pm 19$ & $47 \pm 18.5$ & $44 \pm 23.7$ & 0.007 \\
\hline Admission procalcitonin & $\begin{array}{c}2.3 \\
(\text { IQR } 0.7-7.4)\end{array}$ & $\begin{array}{c}7.9 \\
(\text { IQR 2-33.6) }\end{array}$ & $\begin{array}{c}4.6 \\
\text { (IQR 1.1-11.1) }\end{array}$ & $\begin{array}{c}11.1 \\
(\text { IQR 7-15.3) }\end{array}$ & 0.007 \\
\hline No growth & $86(45.5 \%)$ & $102(65.3 \%)$ & $12(28.5 \%)$ & 0 & $<0.001$ \\
\hline Single site of sepsis & $60(31.7 \%)$ & $35(22.4 \%)$ & $22(52.3 \%)$ & $3(37.5 \%)$ & 0.002 \\
\hline MDR organism & $12(6.3 \%)$ & $22(14.1 \%)$ & $5(11.9 \%)$ & $2(25 \%)$ & 0.05 \\
\hline Fungal sepsis & $11(5.8 \%)$ & $15(9.6 \%)$ & $8(19 \%)$ & $2(25 \%)$ & 0.019 \\
\hline ICU length of stay & $\begin{array}{c}6.5 \\
(\mathrm{IQR} 4.2-44)\end{array}$ & $\begin{array}{c}5.5 \\
\text { (IQR 4-17) }\end{array}$ & $\begin{array}{c}5 \\
\text { (IQR 4-36.5) }\end{array}$ & $\begin{array}{c}7.5 \\
(\text { IQR 5-33.2) }\end{array}$ & 0.003 \\
\hline ICU mortality & $28(14.8 \%)$ & $38(24.4 \%)$ & $6(14.3 \%)$ & $2(25 \%)$ & 0.11 \\
\hline
\end{tabular}

TABLE 4: Multivariate regression analysis to indicate variables associated with no deescalation of antimicrobials.

\begin{tabular}{|c|c|c|c|c|c|}
\hline & \multirow{2}{*}{ Wald statistic } & \multirow{2}{*}{$\operatorname{Exp}(B)$} & \multicolumn{2}{|c|}{$95 \%$ CI for $\operatorname{Exp}(B)$} & \multirow{2}{*}{$p$ value } \\
\hline & & & Lower & Upper & \\
\hline Hematologic malignancy & 8.31 & 3.30 & 1.46 & 7.44 & 0.004 \\
\hline Admission procalcitonin & 9.73 & 1.01 & 1.004 & 1.016 & 0.002 \\
\hline Fungal sepsis & 6.50 & 2.70 & 1.25 & 5.80 & 0.011 \\
\hline MDR organisms isolated & 8.58 & 2.94 & 1.43 & 6.07 & 0.003 \\
\hline SAPS II score & 7.59 & 1.01 & 1.004 & 1.026 & 0.006 \\
\hline
\end{tabular}

admitted "after-hours" and in 50 [89\%] inpatients of 56 culture-positive patients admitted during "regular" hours. Patients with hematologic malignancy comprised 106 (26.8\%) of the admissions; detailed patient characteristics are shown in Table 1.

Empiric antibiotics were a combination of vancomycin, 292 patients (74\%), and carbapenem, 277 patients (70\%), with colistin, 70 patients (18\%), aminoglycosides, 37 (9\%), and quinolones, 64 (16\%), used in addition. Empiric caspofungin was added in 47 (12\%) patients. Most frequent empiric antibiotic regimen used was vancomycin + carbapenem, 193 (49\%), followed by vancomycin + extended-spectrum penicillin/ $\beta$-lactamase inhibitor, 131 (33\%), and vancomycin and aminoglycosides or quinolones, 71 (18\%). Cultures were positive in 195 (49.4\%) patients and 200 (50.6\%) remained culture negative.

Please refer to Table 2 for frequencies of all isolates.

Empiric therapy was appropriate in $57 \%$ cases. The median ICU length of stay was 6 days (IQR 4-43) with a 28day survival rate of $71 \%$ (281 patients).

Antimicrobial deescalation was carried out in 189 (48\%) patients; in 156 (39\%) patients no changes in the antimicrobial regimen were made; 42 (11\%) patients had their antimicrobial coverage escalated and in $8(2 \%)$ patients mixed changes were made.

Please refer to Table 3 for differences in patient characteristics by final antibiotic grouping.

In a comparison of patients that were deescalated compared to patients "not deescalated" (combination of groups with escalation, no changes, or both escalation and deescalation, i.e., mixed changes), rates of malignancy, multidrug resistant (MDR) organisms, fungal sepsis, chronic organ failure (renal, liver), baseline APACHE II, SAPS II, and serum procalcitonin were significantly different. Deescalation rates were not significantly different between patients with positive cultures and those with negative cultures or single versus multiple positive culture sites or when the patient continued to be vasopressor-dependent. Deescalation was associated with a significantly lower ICU mortality compared to patients not deescalated, 27 out of 188 patients (14.3\%) versus 47 out of 207 patients $(22.7 \%)$.

3.1. Univariate Outcome Data. On univariate regression analysis failure to deescalate was significantly predicted by APACHE II and SAPS II scores, OR 1.02 (95\% CI 1.002-1.05, $p=0.037$ ) and OR 1.01 (95\% CI 1.005-1.02, $p=0.004$ ), baseline serum procalcitonin OR 1.01 (95\% CI 1.003-1.016, $p=0.003)$, hematologic malignancy OR 2.85 (95\% CI 1.3$6.2, p=0.009)$, isolation of MDR organisms OR $2.39(95 \%$ CI 1.18-4.8, $p=0.015)$, and fungal sepsis OR 2.21 (95\% CI $1.05-4.62, p=0.035)$.

3.2. Multivariate Analysis. After adjusting for covariates, serum procalcitonin, OR 1.01 (95\% CI 1.004-1.016) $p=0.002$, SAPS II scores OR 1.01 (95\% CI 1.004-1.02), $p=0.006$, hematologic malignancy OR 3.3 (95\% CI 1.4-7.4) $p<0.004$, fungal sepsis OR 2.7 (95\% CI 1.2-5.8) $p=0.011$, and MDR isolates OR 2.9 (95\% CI 1.4-6.0) $p=0.003$ remained significant predictors for no deescalation.

Please refer to Table 4 showing multivariate regression analysis to indicate variables associated with no deescalation of antimicrobials. 
TABle 5: Summary of studies on antibiotic deescalation.

\begin{tabular}{|c|c|c|c|c|c|c|}
\hline & Study type & Setting & Patients & $\begin{array}{l}\text { Deescalation } \\
\text { rate }\end{array}$ & Association with outcomes & $\begin{array}{l}\text { Factors associated with no } \\
\text { deescalation }\end{array}$ \\
\hline $\begin{array}{l}\text { Rello et al., } \\
2004 \text { [2] }\end{array}$ & $\begin{array}{l}\text { Prospective, } \\
\text { observational }\end{array}$ & $\begin{array}{l}\text { Medical- } \\
\text { surgical ICU } \\
\text { with VAP }\end{array}$ & 115 & $31.4 \%$ & Not reported & $\begin{array}{l}\text { Nonfermenting } \\
\text { Gram-negative bacillus } \\
(2.7 \% \text { versus } 49.3 \%), \\
\text { late-onset pneumonia } \\
(12.5 \% \text { versus } 40.7 \%), \\
p<0.05\end{array}$ \\
\hline $\begin{array}{l}\text { Eachempati } \\
\text { et al., } 2009 \\
{[3]}\end{array}$ & Observational & $\begin{array}{l}\text { Surgical ICU } \\
\text { with VAP }\end{array}$ & 138 & $55 \%$ & $\begin{array}{l}\text { No difference in recurrent } \\
\text { pneumonia rate or mortality, } \\
34 \% \text { versus } 42 \%\end{array}$ & Not reported \\
\hline $\begin{array}{l}\text { De Waele et } \\
\text { al., } 2010[4]\end{array}$ & Retrospective & Surgical ICU & 113 & $42 \%$ & $\begin{array}{l}\text { No difference in mortality rate } \\
\text { ( } 7 \% \text { versus } 21 \%, p 0.12 \text { ) }\end{array}$ & $\begin{array}{l}\text { Negative cultures, } \\
\text { colonization with } \\
\text { multiresistant } \\
\text { Gram-negative organisms }\end{array}$ \\
\hline $\begin{array}{l}\text { Hibbard et } \\
\text { al., } 2010[5]\end{array}$ & Retrospective & $\begin{array}{l}\text { Surgical ICU, } \\
\text { VAP }\end{array}$ & $\begin{array}{l}811 \\
\text { antibiotic } \\
\text { days }\end{array}$ & $78 \%-59 \%$ & No change in resistance rates & Not reported \\
\hline $\begin{array}{l}\text { Morel et al., } \\
2010[6]\end{array}$ & Retrospective & Mixed ICU & 116 & $45 \%$ & $\begin{array}{l}\text { Recurrent infection }(19 \% \\
\text { versus } 5 \%, p 0.01)\end{array}$ & $\begin{array}{l}\text { Inadequate empiric } \\
\text { antibiotic and initial } \\
\text { therapy not containing } \\
\text { aminoglycoside }\end{array}$ \\
\hline $\begin{array}{l}\text { Gonzalez et } \\
\text { al., } 2013[7]\end{array}$ & Retrospective & Medical ICU & 229 & $51 \%$ & $\begin{array}{l}\text { No differences in mortality, } \\
\text { length of stay, antibiotic } \\
\text { duration, mechanical } \\
\text { ventilation, ICU-acquired } \\
\text { infection, or drug-resistant } \\
\text { bacteria }\end{array}$ & $\begin{array}{l}\text { Inadequacy of initial } \\
\text { antibiotic therapy }(\mathrm{OR}= \\
0.1,0.0 \text { to } 0.1, p<0.001) \\
\text { multidrug resistant bacteria } \\
(\mathrm{OR}=0.2,0.1 \text { to } 0.7, \\
p=0.006)\end{array}$ \\
\hline $\begin{array}{l}\text { Duchêne et } \\
\text { al., } 2013 \text { [8] }\end{array}$ & Retrospective & Urosepsis & 80 & $46 \%$ & Not reported & $\begin{array}{l}\text { Shock, renal abscess, } \\
\text { obstructive uropathy, } \\
\text { bacterial resistance }\end{array}$ \\
\hline $\begin{array}{l}\text { Garnacho- } \\
\text { Montero et } \\
\text { al., } 2014 \text { [9] }\end{array}$ & $\begin{array}{l}\text { Prospective, } \\
\text { observational }\end{array}$ & Medical & 712 & $34.9 \%$ & $\begin{array}{l}\text { Deescalation protective for } \\
\text { mortality (OR 0.54; } 95 \% \text { CI } \\
0.33-0.89 \text { ) }\end{array}$ & Not reported \\
\hline $\begin{array}{l}\text { Carugati et } \\
\text { al., } 2015[10]\end{array}$ & $\begin{array}{l}\text { Secondary } \\
\text { analysis of CAP } \\
\text { database }\end{array}$ & $\begin{array}{l}\text { Medical with } \\
\text { CAP }\end{array}$ & 261 & $63.2 \%$ & No association with mortality & More severe presentation \\
\hline $\begin{array}{l}\text { Lee et al., } \\
2015 \text { [11] }\end{array}$ & Retrospective & $\begin{array}{l}\text { Community- } \\
\text { onset } \\
\text { monomicrobial } \\
\text { Enterobacteri- } \\
\text { aceae (CoME) } \\
\text { bacteremia }\end{array}$ & 189 & $45.5 \%$ & $\begin{array}{l}\text { Deescalation strategy was } \\
\text { protective for mortality (OR } \\
0.37, p 0.04)\end{array}$ & Not reported \\
\hline
\end{tabular}

Deescalation associated with initial broad-spectrum therapy (OR 1.5, 95\% CI

Madaras-

Kelly et al., 2016 [12]

$\begin{aligned} & \text { HCAP in VA } \\ & \text { system }\end{aligned} \quad 9319 \quad 28.3 \% \quad$ Not reported
P

1.4-1.5), collection of respiratory tract cultures (OR 1.1, 95\% CI 1.0-1.2), care in higher complexity facilities (OR 1.3, 95\% CI 1.1-1.6) 
TABLE 5: Continued.

\begin{tabular}{|c|c|c|c|c|c|c|}
\hline & Study type & Setting & Patients & $\begin{array}{l}\text { Deescalation } \\
\text { rate }\end{array}$ & Association with outcomes & $\begin{array}{l}\text { Factors associated with no } \\
\text { deescalation }\end{array}$ \\
\hline $\begin{array}{l}\text { Falguera et } \\
\text { al., } 2010 \text { [13] }\end{array}$ & RCT & $\begin{array}{l}\text { Community- } \\
\text { acquired } \\
\text { pneumonia }\end{array}$ & $\begin{array}{l}177, \\
\text { deescala- } \\
\text { tion by } \\
\text { urinary } \\
\text { antigen } \\
\text { results }\end{array}$ & - & $\begin{array}{l}\text { Higher cost ( } p 0.28) \text {, reduced } \\
\text { adverse events }(9 \% \text { versus } \\
18 \%, p 0.12) \text {, lower exposure to } \\
\text { broad-spectrum } \\
\text { antimicrobials ( } 154.4 \text { versus } \\
183.3 \text { daily doses per } 100 \\
\text { patient days) }\end{array}$ & \\
\hline $\begin{array}{l}\text { Kim et } \\
\text { al., } 2012 \text { [14] }\end{array}$ & RCT & $\begin{array}{l}\text { Medical ICU, } \\
\text { hospital- } \\
\text { acquired } \\
\text { pneumonia }\end{array}$ & 109 & - & $\begin{array}{l}\text { No differences in ICU stay or } \\
\text { mortality rates, higher risk of } \\
\text { MRSA with deescalation; HR } \\
3.84 ; 95 \% \text { CI } 1.06-13.91\end{array}$ & \\
\hline $\begin{array}{l}\text { Leone et al., } \\
2014 \text { [15] }\end{array}$ & $\begin{array}{l}\text { Multicenter, } \\
\text { RCT }\end{array}$ & Severe sepsis & 60 & - & $\begin{array}{l}\text { Deescalation resulted in } \\
\text { prolonged duration of ICU } \\
\text { stay; mean difference } 3.4(95 \% \\
\text { CI }-1.7-8.5) \text {; no effect on } \\
\text { mortality }\end{array}$ & Not reported \\
\hline
\end{tabular}

ICU: intensive care unit; VAP: ventilator-associated pneumonia; CAP: community-acquired pneumonia; HCAP: healthcare associated pneumonia; HR: hazard ratio; OR: odds ratio.

\section{Discussion}

In this prospective study of critically ill, septic patients antimicrobial deescalation was carried out in less than half of all patients, with higher baseline procalcitonin levels, greater organ dysfunction scores, comorbid hematologic malignancy, isolation of drug-resistant bacteria, and fungal organisms identified as independent predictors of failure to deescalate.

The morbidity and costs of continued broad-spectrum antimicrobials and the safety of deescalation are now well established in the medical literature. A deescalation strategy has not been shown to be harmful in patients with varied immune statuses or systemic or limited infections or in fungal septicemia $[7,11,12,16-25]$ and in fact may even exert a protective effect as reported by Lee et al. [11] and GarnachoMontero et al. [9].

Please see Table 5 for a summary of recent studies on antibiotic deescalation.

Despite reports of benefit, deescalation remains variably practiced with rates from 10 to $60 \%$ [26]. Please refer to Table 5. In our cohort of multidisciplinary critically ill patients with sepsis and shock, antimicrobial deescalation was carried out in $48 \%$ patients, which is comparable to that reported by other investigators.

The real question then is when are physicians less likely to deescalate? Recent studies have shown that antibiotic deescalation becomes less likely with severe, complicated infections and drug-resistance and when initial antibiotic therapy is inadequate. Please refer to Table 5. In our study, deescalation failure was predicted by the isolation of drugresistant bacteria and fungal organisms, greater severity of illness as demonstrated by higher initial organ dysfunction scores, underlying hematologic malignancy, and a procalcitonin level that may suggest a greater bacterial load.

What then appears to be a common theme here is that physicians are uncomfortable deescalating antimicrobials when faced with sicker patients with a higher possibility of complications. Antimicrobial stewardship is a strategy that employs availability of either an infectious disease specialist and/or a clinical pharmacist to assist in decision-making at the bedside. Stewardship programs have been shown to successfully reduce resistance patterns, reduce antibiotic usage, and reduce costs without increasing adverse outcomes [2734]. Our study confirms the results of others that there is a real need for and potential benefits of implementing antimicrobial stewardship programs across all areas where broad-spectrum antimicrobials are utilized. Whether they are specialty driven or pharmacy-led should be tailored to the resources available to individual centers.

This study's strengths are its large numbers of patients and the generalizability of our results to other ICUs. We have a varied case-mix from our surgical and medical ICUs with causative organisms that are similar to those isolated from most ICUs. The limitation of our results is that this is a singlecenter study.

Assisting the stewardship model is a recent publication from de Jong and colleagues [35] where, in a controlled trial in 15 Netherland hospitals, ICU admissions were randomized to usual care versus antibiotic deescalation once procalcitonin levels decreased by $80 \%$ or more of its peak value or to $0.5 \mu \mathrm{g} / \mathrm{L}$ or lower. Mortality was significantly lower in the procalcitonin-guided group, between-group absolute difference 5.4\% (95\% CI 1.2-9.5, $p=0.0122$ ). Therefore, procalcitonin absolute levels and patterns may assist bedside decision-making incorporated into an antibiotic stewardship program.

\section{Conclusions}

Current deescalation practices reflect physician reluctance when dealing with complicated, sicker patients or with drug-resistance or fungal sepsis. Integrating an antibiotic 
stewardship program may increase physician confidence and provide support towards increasing deescalation rates.

\section{Competing Interests}

There are no competing interests to declare.

\section{Acknowledgments}

The authors are indebted to Ahmed Kamal, MD, Assistant Consultant Adult Critical Care Medicine, KFSHRC, for his assistance in data collection.

\section{References}

[1] E. von Elm, M. Egger, D. G. Altman, S. J. Pocock, P. C. Gøtzsche, and J. P. Vandenbroucke, "Strengthening the Reporting of Observational Studies in Epidemiology (STROBE) statement: guidelines for reporting observational studies," British Medical Journal, vol. 335, no. 7624, pp. 806-808, 2007.

[2] J. Rello, L. Vidaur, A. Sandiumenge et al., "De-escalation therapy in ventilator-associated pneumonia," Critical Care Medicine, vol. 32, no. 11, pp. 2183-2190, 2004.

[3] S. R. Eachempati, L. J. Hydo, J. Shou, and P. S. Barie, "Does deescalation of antibiotic therapy for ventilator-associated pneumonia affect the likelihood of recurrent pneumonia or mortality in critically ill surgical patients?" The Journal of Trauma, vol. 66, no. 5, pp. 1343-1348, 2009.

[4] J. J. De Waele, M. Ravyts, P. Depuydt, S. I. Blot, J. Decruyenaere, and D. Vogelaers, "De-escalation after empirical meropenem treatment in the intensive care unit: fiction or reality?" Journal of Critical Care, vol. 25, no. 4, pp. 641-646, 2010.

[5] M. L. Hibbard, T. R. Kopelman, P. J. O’Neill et al., "Empiric, broad-spectrum antibiotic therapy with an aggressive deescalation strategy does not induce gram-negative pathogen resistance in ventilator-associated pneumonia," Surgical Infections, vol. 11, no. 5, pp. 427-432, 2010.

[6] J. Morel, J. Casoetto, R. Jospé et al., "De-escalation as part of a global strategy of empiric antibiotherapy management. A retrospective study in a medico-surgical intensive care unit," Critical Care, vol. 14, no. 6, article R225, 2010.

[7] L. Gonzalez, A. Cravoisy, D. Barraud et al., "Factors influencing the implementation of antibiotic de-escalation and impact of this strategy in critically ill patients," Critical Care, vol. 17, no. 4, article R140, 2013.

[8] E. Duchêne, E. Montassier, D. Boutoille, J. Caillon, G. Potel, and E. Batard, "Why is antimicrobial de-escalation underprescribed for urinary tract infections?" Infection, vol. 41, no. 1, pp. 211-214, 2013.

[9] J. Garnacho-Montero, A. Gutiérrez-Pizarraya, A. EscorescaOrtega et al., "De-escalation of empirical therapy is associated with lower mortality in patients with severe sepsis and septic shock," Intensive Care Medicine, vol. 40, no. 1, pp. 32-40, 2014.

[10] M. Carugati, F. Franzetti, T. Wiemken et al., "De-escalation therapy among bacteraemic patients with community-acquired pneumonia," Clinical Microbiology and Infection, vol. 21, no. 10, pp. 936.e11-936.e18, 2015.

[11] C.-C. Lee, N.-Y. Lee, P.-L. Chen et al., "Impact of antimicrobial strategies on clinical outcomes of adults with septic shock and community-onset Enterobacteriaceae bacteremia: de-escalation is beneficial," Diagnostic Microbiology and Infectious Disease, vol. 82, no. 2, pp. 158-164, 2015.

[12] K. Madaras-Kelly, M. Jones, R. Remington et al., "Antimicrobial de-escalation of treatment for healthcare-associated pneumonia within the Veterans Healthcare Administration," The Journal of Antimicrobial Chemotherapy, vol. 71, no. 2, pp. 539-546, 2016.

[13] M. Falguera, A. Ruiz-González, J. A. Schoenenberger et al., "Prospective, randomised study to compare empirical treatment versus targeted treatment on the basis of the urine antigen results in hospitalised patients with community-acquired pneumonia," Thorax, vol. 65, no. 2, pp. 101-106, 2010.

[14] J. W. Kim, J. Chung, S.-H. Choi et al., "Early use of imipenem/ cilastatin and vancomycin followed by de-escalation versus conventional antimicrobials without de-escalation for patients with hospital-acquired pneumonia in a medical ICU: a randomized clinical trial," Critical Care, vol. 16, no. 1, article R28, 2012.

[15] M. Leone, C. Bechis, K. Baumstarck et al., "De-escalation versus continuation of empirical antimicrobial treatment in severe sepsis: a multicenter non-blinded randomized noninferiority trial," Intensive Care Medicine, vol. 40, no. 10, pp. 1399-1408, 2014.

[16] M. K. Joung, J.-A. Lee, S.-Y. Moon et al., "Impact of deescalation therapy on clinical outcomes for intensive care unitacquired pneumonia," Critical Care, vol. 15, no. 2, article R79, 2011.

[17] N. Shime, S. Satake, and N. Fujita, "De-escalation of antimicrobials in the treatment of bacteraemia due to antibiotic-sensitive pathogens in immunocompetent patients," Infection, vol. 39, no. 4, pp. 319-325, 2011.

[18] K. S. Kaye, "Antimicrobial de-escalation strategies in hospitalized patients with pneumonia, intra-abdominal infections, and bacteremia," Journal of Hospital Medicine, vol. 7, supplement 1, pp. S13-S21, 2012.

[19] K. V. I. Rolston, S. N. Mahajan, and R. F. Chemaly, "Antimicrobial de-escalation in cancer patients," Infection, vol. 40, no. 2, pp. 223-224, 2012.

[20] A. Apisarnthanarak, N. Bhooanusas, A. Yaprasert, and L. M. Mundy, "Carbapenem de-escalation therapy in a resourcelimited setting," Infection Control and Hospital Epidemiology, vol. 34, no. 12, pp. 1310-1313, 2013.

[21] M. J. Mosier and H. Ton-That, "Making the case for deescalation therapy in ventilator-associated pneumonia once again," Critical Care Medicine, vol. 41, no. 7, pp. 1810-1811, 2013.

[22] R. G. Masterton, M. Casamayor, P. Musingarimi et al., "Deescalation from micafungin is a cost-effective alternative to traditional escalation from fluconazole in the treatment of patients with systemic Candida infections," Journal of Medical Economics, vol. 16, no. 11, pp. 1344-1356, 2013.

[23] S. Bailly, O. Leroy, P. Montravers et al., "Antifungal de-escalation was not associated with adverse outcome in critically ill patients treated for invasive candidiasis: post hoc analyses of the AmarCAND2 study data," Intensive Care Medicine, vol. 41, no. 11, pp. 1931-1940, 2015.

[24] D. Mokart, G. Slehofer, J. Lambert et al., "De-escalation of antimicrobial treatment in neutropenic patients with severe sepsis: results from an observational study, Intensive Care Medicine, vol. 40, no. 1, pp. 41-49, 2014.

[25] F. A. Khasawneh, A. Karim, T. Mahmood et al., "Antibiotic de-escalation in bacteremic urinary tract infections: potential opportunities and effect on outcome," Infection, vol. 42, no. 5, pp. 829-834, 2014. 
[26] J. Garnacho-Montero, A. Escoresca-Ortega, and E. FernándezDelgado, "Antibiotic de-escalation in the ICU: how is it best done?" Current Opinion in Infectious Diseases, vol. 28, no. 2, pp. 193-198, 2015.

[27] S. Cheon, M. J. Kim, S. J. Yun, J. Y. Moon, and Y. S. Kim, "Controlling endemic multidrug-resistant Acinetobacter baumannii in intensive care units using antimicrobial stewardship and infection control," The Korean Journal of Internal Medicine, vol. 31, no. 2, pp. 367-374, 2016.

[28] L. R. Taggart, E. Leung, M. P. Muller, L. M. Matukas, and N. Daneman, "Differential outcome of an antimicrobial stewardship audit and feedback program in two intensive care units: a controlled interrupted time series study," BMC Infectious Diseases, vol. 15, no. 1, article 480, 2015.

[29] A. Hohn, B. Heising, S. Hertel, G. Baumgarten, M. Hochreiter, and S. Schroeder, "Antibiotic consumption after implementation of a procalcitonin-guided antimicrobial stewardship programme in surgical patients admitted to an intensive care unit: a retrospective before-and-after analysis," Infection, vol. 43, no. 4, pp. 405-412, 2015.

[30] D. Hou, Q. Wang, C. Jiang, C. Tian, H. Li, and B. Ji, "Evaluation of the short-term effects of antimicrobial stewardship in the intensive care unit at a tertiary hospital in China," PLoS ONE, vol. 9, no. 7, article e101447, 2014.

[31] M. O. Cotta, J. A. Roberts, A. Tabah, J. Lipman, D. Vogelaers, and S. Blot, "Antimicrobial stewardship of $\beta$-lactams in intensive care units," Expert Review of Anti-Infective Therapy, vol. 12, no. 5, pp. 581-595, 2014.

[32] M. R. Amer, N. S. Akhras, W. A. Mahmood, and A. S. AlJazairi, "Antimicrobial stewardship program implementation in a medical intensive care unit at a tertiary care hospital in Saudi Arabia," Annals of Saudi Medicine, vol. 33, no. 6, pp. 547-554, 2013.

[33] Y. Ramsamy, D. J. J. Muckart, and K. S. S. Han, "Microbiological surveillance and antimicrobial stewardship minimise the need for ultrabroad-spectrum combination therapy for treatment of nosocomial infections in a trauma intensive care unit: an audit of an evidence-based empiric antimicrobial policy," South African Medical Journal, vol. 103, no. 6, pp. 371-376, 2013.

[34] D. Slain, A. R. Sarwari, K. O. Petros et al., "Impact of a multimodal antimicrobial stewardship program on Pseudomonas aeruginosa susceptibility and antimicrobial use in the intensive care unit setting," Critical Care Research and Practice, vol. 2011, Article ID 416426, 5 pages, 2011.

[35] E. de Jong, J. A. van Oers, A. Beishuizen et al., "Efficacy and safety of procalcitonin guidance in reducing the duration of antibiotic treatment in critically ill patients: a randomised, controlled, open-label trial," The Lancet Infectious Diseases, vol. 16, no. 7, pp. 819-827, 2016. 


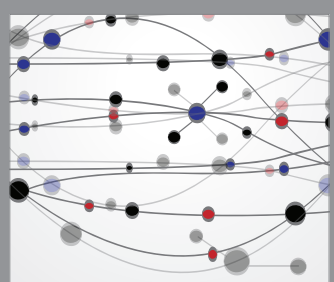

The Scientific World Journal
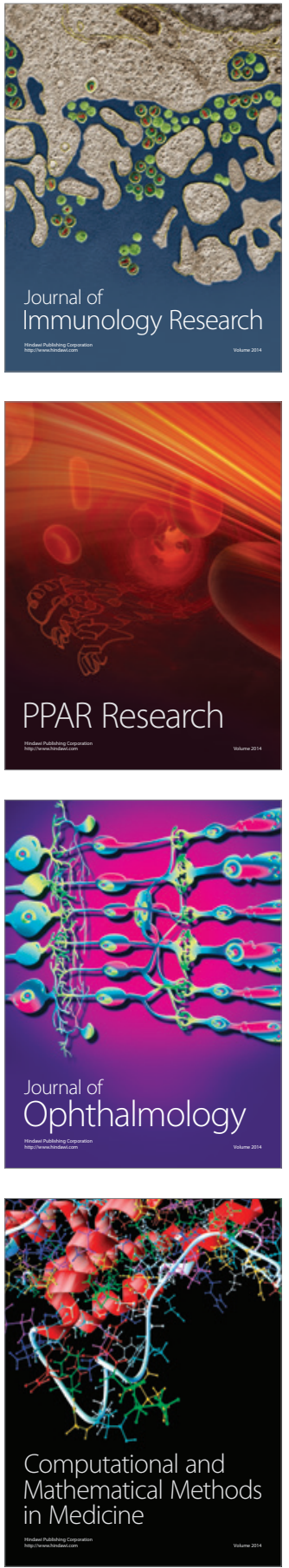

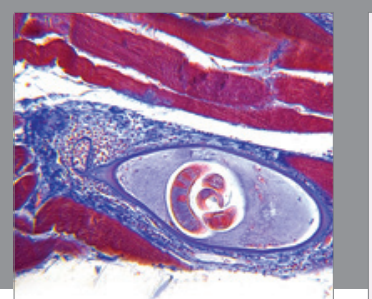

Gastroenterology Research and Practice

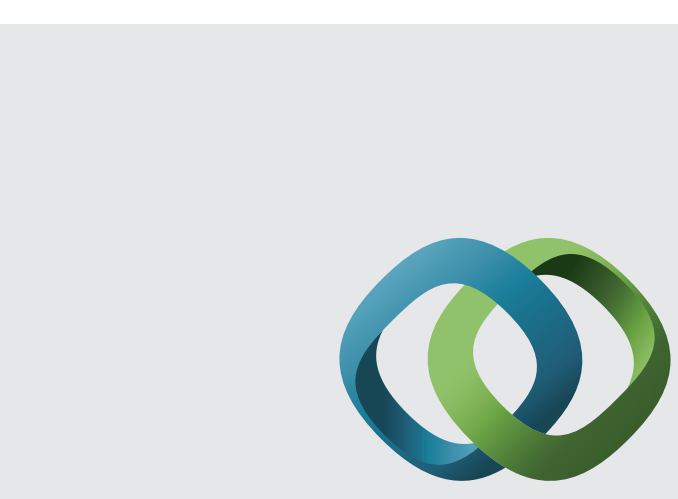

\section{Hindawi}

Submit your manuscripts at

http://www.hindawi.com
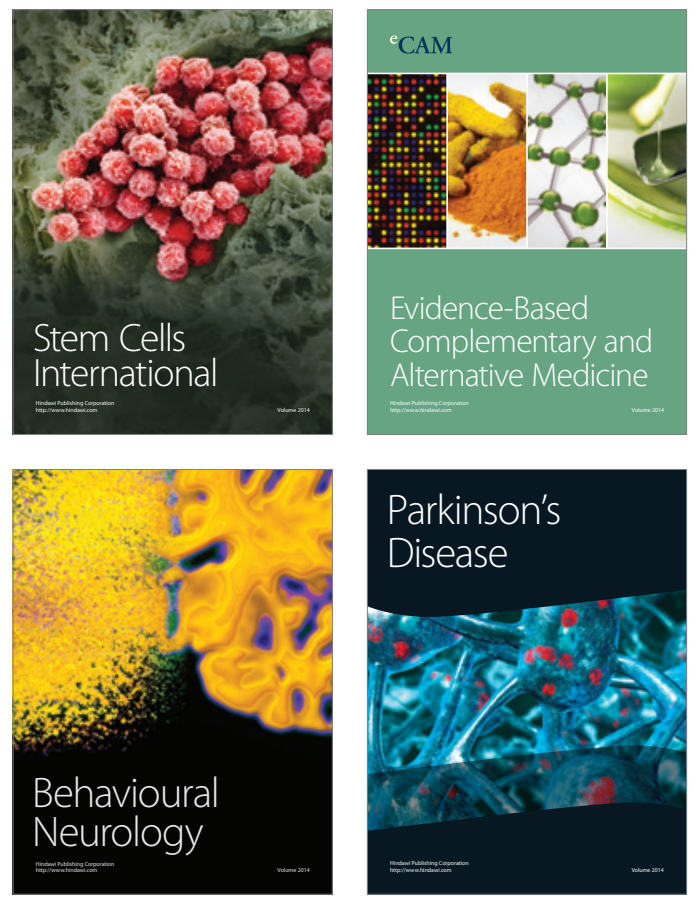
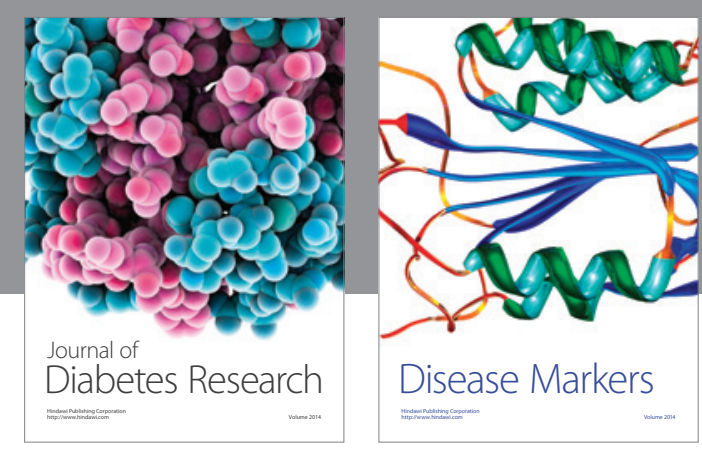

Disease Markers
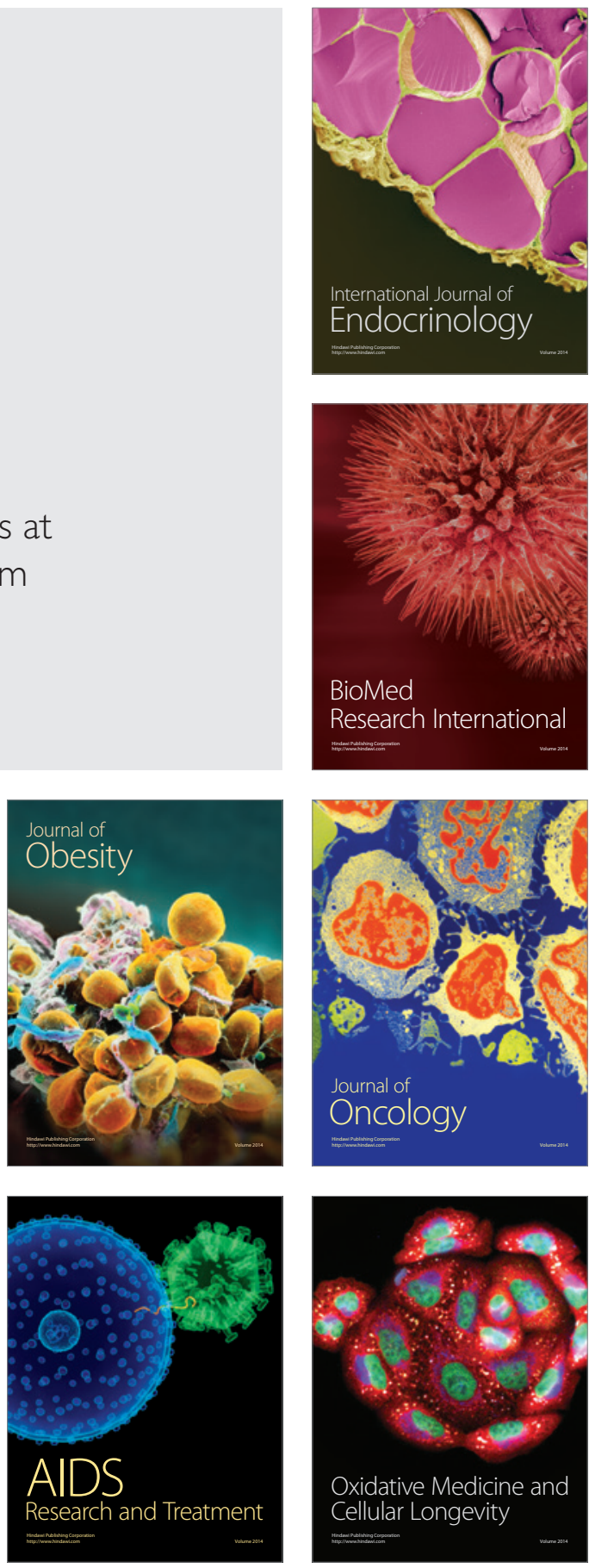